\title{
Karakterisasi Keluhan Muskuloskeletal Akibat Postur Kerja Buruk Pada Pekerja Industri Kecil Makanan
}

\author{
Luciana Triani Dewi ${ }^{1}$
}

\begin{abstract}
The study was originated from the result of observation on production activity of small food industries in Yogyakarta that showed various awkward postures. Awkward posture will lead to continual static loading on soft tissue which potentially cause musculoskeletal disorders and further will affect worker productivity and performance. The aims of the study were to identify and characterize musculoskeletal symptoms among small food industry worker in Yogyakarta. The subjects of this study were one hundred worker of small food industry in Yogyakarta. The identification used standardized Nordic Questionnaire to evaluate musculoskeletal symptoms on 28 body parts in two time periods: recent twelve months and recent seven days. The result of this study indicated that 100\% participants reported experiencing discomfort at least in one body part in the previous twelve months and $89 \%$ of them reported the same thing in the seven-day period. Statistical analysis showed significant difference between musculoskeletal symptoms taking place in the twelve-month period and those in the seven-day period. Musculoskeletal symptoms primarily took place on waist. The lowest prevalence for twelve-month period and seven-day one were left elbow (29\%) and left leg (5\%), respectively.
\end{abstract}

Keywords. awkward posture, food industry, musculoskeletal symptoms

\begin{abstract}
Abstrak. Observasi terhadap pekerja industri kecil makanan di Yogyakarta ditemukan berbagai postur kerja buruk pada proses produksinya. Postur kerja buruk menyebabkan pembebanan statis secara kontinyu sehingga berpotensi terjadi gangguan muskuloskeletal dan dapat berdampak pada performansi dan produktivitas pekerja. Artikel ini melakukan identifikasi dan pemetaan karakter keluhan musculoskeletal yang dialami pekerja industri kecil makanan. Seratus pekerja sebagai subjek dalam penelitian ini. Identifikasi keluhan musculoskeletal menggunakan kuesioner serupa Nordic Questionnaire, berupa lembar isian keluhan akibat kerja yang dirasakan pekerja pada setiap segmen tubuh dalam deriode 12 bulan dan 7 hari terakhir. Hasil studi menunjukkan 100\% pekerja mengalami keluhan muskuloskeletal dalam 12 bulan terakhir dan 89\% mengalami keluhan dalam 7 hari terakhir. Analisis statistik menunjukkan adanya perbedaan signifikan keluhan muskuloskeletal pekerja dalam 12 bulan terakhir dan dalam 7 hari terakhir untuk 28 anggota badan yang dievaluasi. Dalam 12 bulan terakhir prevalensi terbesar untuk jumlah 6 sampai dengan 10 anggota badan (28\%), sedangkan dalam 7 hari terakhir prevalensi terbesar untuk jumlah anggota badan 1 sampai dengan 5 (40\%). Keluhan muskuloskeletal paling tinggi terjadi untuk segmen pinggang. Prevalensi paling rendah adalah segmen siku kiri untuk 12 bulan terakhir (29\%) dan dalam 7 hari terakhir adalah segmen kaki kiri $(5 \%)$.
\end{abstract}

Kata kunci. Industri makanan, keluhan muskuloskeletal, postur kerja buruk

\section{Pendahuluan}

Gangguan muskuloskeletal akibat kerja atau work related musculoskeletal disorders (WMSD) merupakan gangguan yang mengakibatkan

\footnotetext{
${ }^{1}$ Luciana TrianiDewi, Prodi TeknikIndustri,

FakultasTeknologiIndustri, UniversitasAtma Jaya

Yogyakarta, (email: triani.dewi@mail.uajy.ac.id)
}

Diajukan: 23-09-2016

Disetujui: $14-12-2016$ kerusakan struktur pada tendon, otot, tulang dan persendian, syaraf dan system pembuluh darah (Simoneau, dkk, 1996). WMSD secara signifikan menjadi penyebab utama cedera industri baik di negara-negara maju maupun negara berkembang (Pollak \& Castillo, 2014; Shahnavaz, 1987). Prevalensi WMSD di Indonesia terjadi pada kelompok pekerja di berbagai sektor. Penelitian di 8 (delapan) sektor yang berbeda di tanah air menyebutkan bahwa WMSD dialami oleh 31,6\% petani kelapa sawit di Riau, $18 \%$ perajin onyx di Jawa Barat, $16,4 \%$ penambang emas di 
Kalimantan Barat, 14,9\% perajin sepatu di Bogor, dan $8 \%$ perajin kuningan di Jawa Tengah, $76,7 \%$ perajin batu bata di Lampung dan $41,6 \%$ nelayan di DKI Jakarta (Riyadina dkk., 2008). Faktor resiko yang menyebabkan terjadinya WMSD pada aktivitas kerja antara lain adalah beban kerja (work load), postur kerja, pengulangan (repetisi) dan durasi aktivitas (Bridger, 2003). Postur kerja buruk menyebabkan pembebanan statis pada jaringan lunak tertentu secara kontinyu sehingga berpotensi terjadi gangguan dan penurunan kondisi otot, tulang dan sendi dan pada akhirnya dapat berdampak pada performansi kerja dan produktivitas pekerja.

Berdasarkan artikel ilmiah terdahulu, keluhan musculoskeletal pekerja industri disebabkan oleh berbagai faktor, antara lain postur kerja (Quansah, 2005; Velaga \& Telaprolu, 2013), kondisi tempat kerja dan faktor individu (Hagberg, dkk., 2002) dan faktor-faktor psikososial (Mehrdad, dkk., 2010). Studi terdahulu mengevaluasi prevalensi keluhan muskuloskeletal di berbagai negara, tempat kerja dan berbagai jenis pekerjaan (Leroux, dkk., 2005; Elfering, dkk., 2008; Buettner, dkk., 2008; Alazawi, 2012).

Penelitian ini fokus pada industri mikro kecil (IMK) sektor makanan di Yogyakarta. Data BPS melaporkan bahwa IMK sektor makanan merupakan salah satu golongan industri yang yang mendominasi di Yogyakarta dari aspek jumlah populasi, penyerapan tenaga kerja dan nilai investasi pada tahun 2013 (BPS DIY, 2014). IMK sektor makanan di Yogyakarta menunjukkan pertumbuhan positif pada triwulan III tahun 2014. Pertumbuhan ini didukung oleh sektor pariwisata, dimana Yogyakarta merupakan salah satu tujuan wisata yang menarik bagi wisatawan. Pada umumnya IMK makanan di Yogyakarta merupakan industri sederhana yang dilakukan di tempat kerja yang terbatas. Observasi umum terhadap beberapa IMK makanan di Yogyakarta ditemukan prevalensi postur kerja buruk yang cukup signifikan pada proses produksinya. Beberapa postur kerja buruk yang dijumpai seperti postur membungkuk, duduk menyilang, jongkok, berlutut, dan postur non natural lainnya. Postur kerja buruk tersebut pada umumnya terjadi secara repetitif atau kontinyu sepanjang waktu kerja.

Tujuan penelitian ini adalah melakukan identifikasi dan pemetaan karakter keluhan muskuloskeletal yang dialami pekerja IMK makanan di Yogyakarta. Hasil karakterisasi ini dapat digunakan sebagai dasar melakukan evaluasi penyebab keluhan muskuloskeletal yang dialami pekerja IMK makanan di Yogyakarta untuk selanjutnya dapat dikembangkan langkahlangkah pengendalian.

\section{Metodologi}

Subjek studi ini adalah 100 (seratus) pekerja industri kecil makanan di berbagai wilayah di Yogyakarta yang ditentukan dengan simple random sampling. Subjek terdiri dari 47 pekerja laki-laki dan 53 pekerja perempuan. Rentang usia pekerja antara 16 tahun sampai dengan 66 tahun (dengan rata-rata $+\sigma: 31,1$ tahun $+19,5$ ). Rentang masa kerja responden antara 3 bulan sampai dengan 40 tahun (dengan rata-rata $+\sigma$ : $3,7$ tahun $+6,5)$.

Kuesioner terbuka diberikan kepada subjek untuk mendapatkan informasi tentang usia, jenis kelamin dan masa kerja serta upaya terapi atau pengobatan yang biasa dilakukan jika mengalami keluhan muskuloskeletal.

Identifikasi keluhan musculoskeletal disorder menggunakan kuesioner serupa Nordic Questionnaire (NQ) (Kourinka, dkk., 1987). Kuesioner yang digunakan berupa lembar isian tentang adanya keluhan akibat kerja yang dirasakan pekerja pada setiap segmen tubuh. Jumlah segmen tubuh yang dievaluasi sebanyak 28 segmen yang diberi notasi angka 0 sampai dengan 27. Untuk memudahkan evaluasi, lembar isian dilengkapi dengan body map seperti pada Gambar 1. Keluhan akibat kerja yang dirasakan meliputi rasa sakit, nyeri, kesemutan, kram, kaku dan rasa tidak nyaman lainnya yang dievaluasi untuk dua periode yaitu dalam 12 bulan terakhir dan dalam 7 hari terakhir. Analisis statistik deskriptif kuantitatif digunakan dalam penelitian ini untuk menunjukkan prevalensi karakter keluhan muskuloskeletal yang dialami pekerja. Uji statistik non parametrik dua sampel terikat Friedman test dilakukan untuk menentukan signifikansi perbedaan keluhan muskuloskeletal dalam 12 bulan dan 7 hari terakhir dengan tingkat signifikansi $\mathrm{p}<0,05$. 


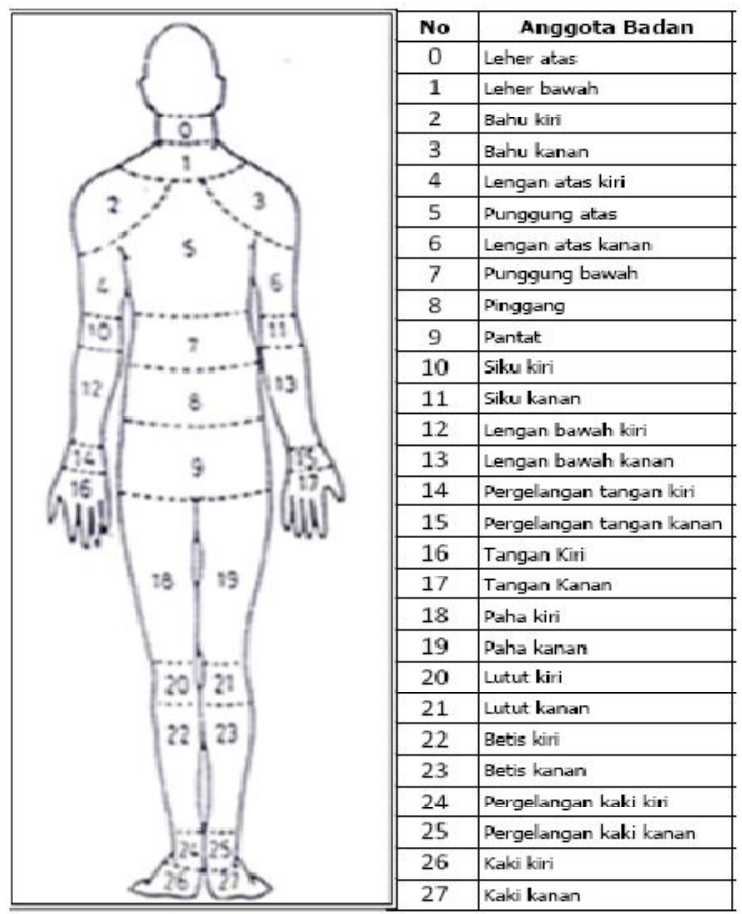

Gambar 1. Body map dalam kuesioner keluhan muskuloskeletal

\section{HASIL DAN PEMBAHASAN}

Hasil identifikasi menunjukkan 100\% pekerja mengalami keluhan muskuloskeletal dalam 12 bulan terakhir pada sedikitnya satu anggota badan dengan total jumlah keluhan 1526. Prevalensi pekerja yang mengalami keluhan pada sedikitnya satu anggota badan dalam 7 hari terakhir sebanyak 89 orang $(89 \%)$ dengan total jumlah keluhan 641. Terjadi penurunan keluhan dalam 12 bulan terakhir dan 7 hari terakhir sebesar $42 \%$. Jumlah anggota badan yang dikeluhkan bervariasi. Dalam 12 bulan terakhir prevalensi terbesar untuk jumlah 6 sampai dengan 10 anggota badan (28\%), sedangkan dalam 7 hari

Tabel 1. Prevalensi berdasarkan jumlah anggota badan yang dikeluhkan $(\mathrm{n}=100)$

\begin{tabular}{ccc}
\hline $\begin{array}{c}\text { Jumlah anggota } \\
\text { badan yang } \\
\text { dikeluhkan }\end{array}$ & $\begin{array}{c}\text { Prevalensi } \\
\text { dalam 12 bulan } \\
\text { terakhir (\%) }\end{array}$ & $\begin{array}{c}\text { Prevalensi } \\
\text { dalam 7 hari } \\
\text { terakhir (\%) }\end{array}$ \\
\hline 0 & 0 & 11 \\
1 s.d 5 & 22 & 40 \\
6 s.d 10 & 28 & 30 \\
11 s.d 15 & 21 & 12 \\
16 s.d 20 & 23 & 4 \\
$>20$ & 6 & 3 \\
\hline
\end{tabular}

terakhir prevalensi terbesar untuk jumlah anggota badan 1 sampai dengan 5 (40\%). Tabel 1 menunjukkan prevalensi berdasarkan jumlah anggota badan yang dikeluhkan dalam 12 bulan dan 7 hari terakhir.

Keluhan muskuloskeletal dalam 6 bulan terakhir relatif seimbang untuk jumlah anggota badan yang dikeluhkan 1 sampai 5, 6 sampai 10; 11 sampai 15, dan 16 sampai 20. Prevalensi dalam 7 hari terakhir menunjukkan peningkatan untuk jumlah anggota badan yang dikeluhkan sebesar 0, 1 sampai 5, dan 6 sampai 10, dan menunjukkan penurunan untuk jumlah anggota badan yang dikeluhkan 11 sampai 15; 16 sampai 20, dan lebih dari 20.

Secara keseluruhan, dalam 7 hari terakhir terjadi penurunan keluhan muskuloskeletal yang dialami pekerja dibandingkan dalam 12 bulan terakhir. Interpretasi dari prevalensi ini adalah menunjukkan adanya upaya pekerja untuk mengatasi atau memulihkan keluhan muskuloskeletal yang dialami akibat pekerjaannya. Berdasarkan wawancara, beberapa upaya yang dilakukan antara lain: (1) melakukan terapi ke ahli pijat/urut; (2) konsumsi obat penghilang nyeri otot yang dijual bebas dan (3) swa terapi menggunakan balsem gosok atau 


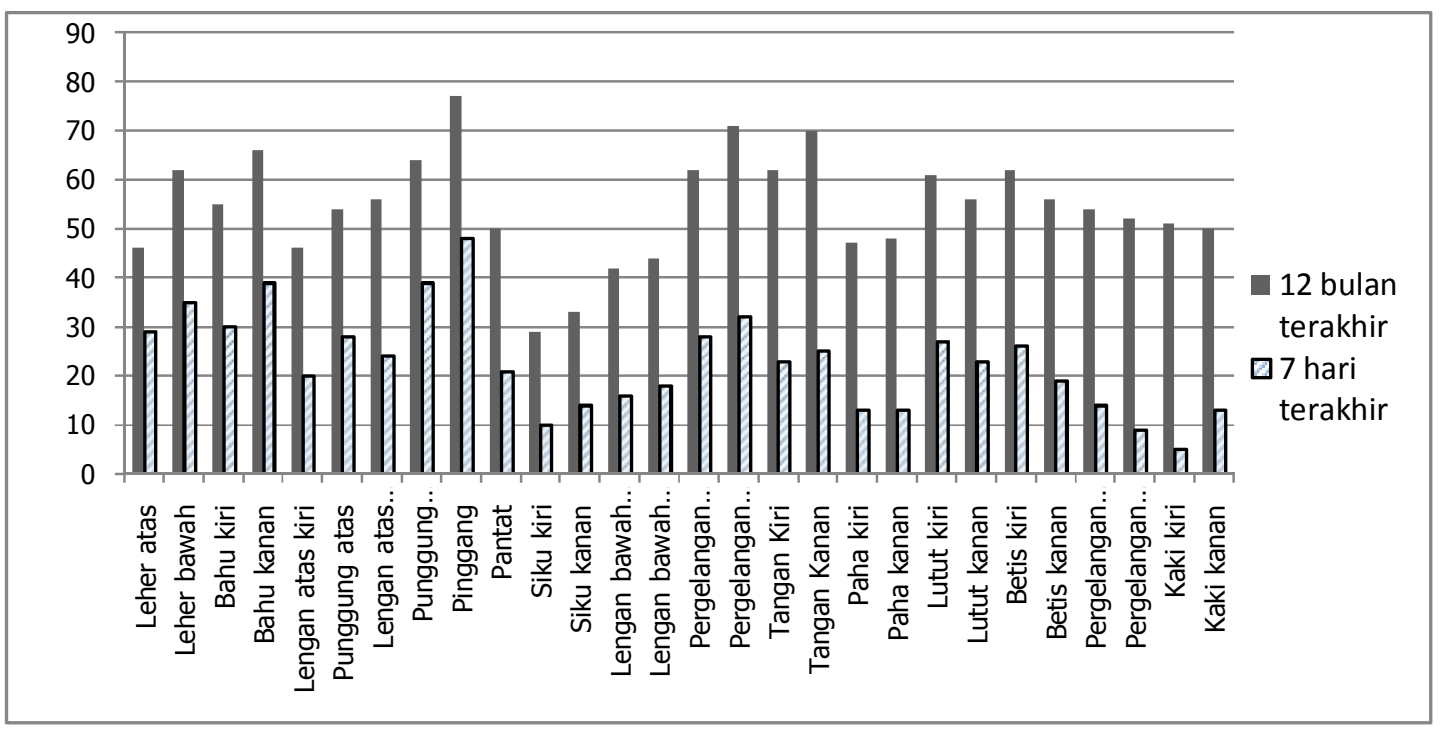

Gambar 2. Prevalensi keluhan setiap anggota tubuh (\%) dalam 12 bulan dan 7 hari terakhir

minyak urut saat mengalami keluhan muskuloskeletal.

Keluhan muskuloskeletal dalam 12 bulan terakhir dan dalam 7 hari terakhir paling tinggi terjadi pada segmen pinggang, yaitu $77 \%$ dalam 12 bulan terakhir dan $48 \%$ dalam 7 hari terakhir. Prevalensi ini menunjukkan bahwa pinggang merupakan bagian tubuh yang selayaknya menjadi fokus perhatian bagi pekerja industri makanan di Yogyakarta. Keluhan pada pinggang dapat terjadi karena postur kerja membungkuk, memutar atau jongkok. Penelusuran lebih rinci diperlukan untuk dapat menentukan langkahlangkah pengendaliannya. Menurut NIOSH (2009), keluhan muskuloskeletal pada segmen pinggang termasuk dalam low back pain yang pada umumnya disebabkan postur kerja buruk dan gerakan berulang yang memaksa kerja otot dan sendi tulang belakang. Apabila gerakan dilakukan dalam durasi lama, maka akan membuat otot terus menerus berkontraksi sehingga menimbulkan ketegangan dan stress pada bagian pinggang. Meskipun demikian, hasil penelitian menunjukkan terjadi penurunan prevalensi keluhan pada segmen pinggang dari 12 bulan terakhir dan 7 hari terakhir (77\% vs $48 \%$ ). Hal ini mengindikasikan bahwa pekerja yang mengalami keluhan berusaha melakukan upaya untuk mengatasi keluhan muskuloskeletal pada segmen pinggang dan sebagian upaya menunjukkan hasil positif, ditandai dengan penurunan prevalensi pada 7 hari terakhir.
Prevalensi paling rendah adalah segmen siku kiri untuk 12 bulan terakhir (29\%) dan dalam 7 hari terakhir adalah segmen kaki kiri (5\%). Gambar 2 menunjukkan histogram prevalensi keluhan muskuloskeletal untuk setiap segmen tubuh. Tidak ditemukan segmen tubuh yang tanpa keluhan baik dalam 12 bulan maupun 7 hari terakhir.

Hasil analisis statistik Friedman Test menunjukkan adanya signifikansi perbedaan keluhan muskuloskeletal dalam 12 bulan terakhir dan dalam 7 hari terakhir, $\chi 2(1)=28 ; p=0,00$. Hasil uji ditunjukkan pada Gambar 3.

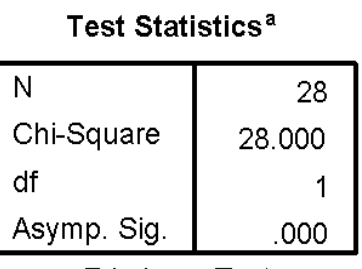

Gambar 3. Hasil uji statistik Friedman test

Hasil pengujian statistik mengindikasikan penurunan signifikan keluhan muskuloskeletal dalam 7 hari terakhir dibandingkan keluhan dalam 12 bulan terakhir. Jenis gangguan muskuloskeletal dibedakan menjadi dua yaitu gangguan acute dan gangguan chronic (Luttmann dkk, 2003). Jenis yang pertama disebabkan beban berat seketika dan menyebabkan kerusakan 
kompenen sistem muskuloskeletal secara langsung, seperti fracture (patah tulang), tulang retak, sendi geser, terkilir, dan kram otot. Jenis kedua disebabkan pembebanan pada sistem muskuloskeletal secara permanen dalam jangka panjang dan mengakibatkan degenerasi komponen sistem muskuloskeletal. Secara keseluruhan, ada prevalensi gangguan muskuloskeletal jenis acute yang dialami pekerja. Jenis gangguan muskuloskeletal acute tidak bisa diabaikan dan prevalensi menunjukkan penurunan sebesar $42 \%$ keluhan dialami pekerja dalam 7 hari terakhir. Meskipun demikian, prevalensi gangguan muskuloskeletal jenis chronic lebih tinggi daripada jenis acute, dapat dilihat dari hasil uji statistik yang menunjukkan signifikansi perbedaan keluhan muskuloskeletal dalam 12 bulan terakhir dan dalam 7 hari terakhir. Penurunan prevalensi terbesar dalam 12 bulan terakhir dan dalam 7 hari terakhir terjadi untuk segmen kaki kiri (51\% menjadi 5\%) diikuti oleh segmen tangan kanan (75\% menjadi $25 \%$ ). Hal ini menunjukkan untuk gangguan muskuloskeletal pada kaki dan tangan dominan untuk jenis chronic yang dapat segera dipulihkan dengan upaya-upaya yang dilakukan pekerja seperti telah dijelaskan sebelumnya.

\section{SIMPULAN}

Keluhan muskuloskeletal terutama terjadi pada segmen tubuh pinggang. Prevalensi ini menunjukkan bahwa pinggang merupakan bagian tubuh yang selayaknya menjadi fokus perhatian bagi pekerja industri makanan di Yogyakarta. Keluhan pada pinggang dapat terjadi karena postur kerja membungkuk, memutar atau jongkok. Penelusuran lebih rinci diperlukan untuk dapat menentukan langkah-langkah pengendaliannya. Jenis keluhan muskuloskeletal acute tidak bisa diabaikan dan prevalensi menunjukkan sebesar $89 \%$ keluhan masih dialamai pekerja dalam 7 hari terakhir. Prevalensi gangguan muskuloskeletal jenis chronic lebih tinggi daripada jenis acute dan terutama terjadi pada anggota badan kaki dan tangan.

Berdasarkan hasil yang diperoleh, lebih lanjut dapat dilakukan identifikasi resiko gangguan muskuloskeletal untuk menilai seberapa besar tingkat resiko bahaya dari aktivitas kerja yang dilakukan pekerja. Hasil karakterisasi keluhan dan penilaian resiko bahaya muskuloskeletal dapat digunakan sebagai input dalam merancang langkah-langkah pengendalian.

\section{UCAPAN TERIMA KASIH}

Terima kasih kepada Kementrian Riset Teknologi dan Pendidikan Tinggi serta Universitas Atma Jaya Yogyakarta atas dukungan dalam pelaksanaan penelitian ini melalui Hibah Penelitian Riset Terapan Tahun 2016.

\section{DAFTAR PUSTAKA}

Alazawi, S.A. 2012. "Prevalence of musculoskeletal symptoms among visual display terminal users". Tikrit Medical Journal, Vol. 18 (1), pp. 127 - 132.

BPS DIY. 2014. "Pertumbuhan produksi industry manufaktur besar dan industry mikro kecil triwulan III 2014”. Berita Resmi Statistik Provinsi DIY, edisi 63/11/34/XIV, pp. $1-6$.

Bridger, R. 2003. Introduction to Ergonomics. London: Taylor \& Francis.

Buettner, C.; Davis, R.B.; Leveille, S.G.; Mittleman, M.A.; Mukamal, K.J. 2008. "Prevalence of musculoskeletal pain and statin use". Journal of General Internal Medicine, Vol. 23 (8), pp. $1182-1186$.

Elfering, A.; Grebner, S.; Gerber, H.; Semmer, N. 2008. "Workplace observation of work stressors, catecholamines and musculoskeletal pain among male employees". Scandinavian Journal of Work, Environment \& Health, Vol. 34 (5), pp. 337 - 344.

Hagberg, M.; Tornqvist, E.W.; Toomingas, A. 2002. "Selfreported reduced productivity due to musculoskeletal symptoms: associations with workplace and individual factors among white-collar computer users". Journal of Occupational Rehabilitation, Vol. 12 (3), pp. 151-162.

Helander, M. 2006. A Guide to Human Factors and Ergonomics. New York: Taylor \& Francis

Kuorinka, I.; Jonsson, B.; Kilbom, A.; Vinterberg, H.; Sorensen, B.F.; Andersson, G.; Jorgensen, K. 1987. "Standardised nordic questionnaires for the analysis of musculoskeletal symptoms". Applied Ergonomics, Vol. 18 (3), pp. $233-237$.

Leroux, I.; Dionne, C.E.; Bourbonnais, R.; Brisson, C. 2005. "Prevalence of musculoskeletal pain and associated factors in the Quebec working population". International Archives of Occupational and Environmental Health, Vol. 78 (5), pp. $379-386$.

Luttmann, A.; Jager, M.; Griefahn, B. 2003. Preventing Musculoskeletal Disorders in The Workplace. Berlin: WHO Publications.

Mehrdad, R.; Dennerlein, J.T.; Haghighat, M.; Aminian, O. 2010. "Association between psychosocial factors and musculoskeletal symptoms among Iranian nurses". American Journal of Industrial Medicine, Vol. 53 (10), pp. $1032-1039$.

NIOSH. 2009. Ergonomics Risk Factors-Awkward Posture. (http://www.imana.org/IMANA/files/ccLibraryFiles/File name/000000000426/4Risk_FactorsAwkwardPostures.p df). Online: diunduhFebruari 2015 
Pollak, N. A.; Castillo, W. S. 2014. Trends in Workplace MSDs. (http://www.boneandjointburden.org/2014report/vib1/trends-workplace-msds). Online: diunduh February 2015.

Quansah, R. 2005. "Harmful postures and musculoskeletal symptoms among sanitation workers of a fish processing factory in Ghana: A preliminary investigation". International Journal of Occupational Safety and Ergonomics, Vol. 11 (2), pp. 171-180.

Riyadina, W.;Suharyanto, F.; \& Tana, L. 2008. "Keluhan nyeri musculoskeletal pada pekerja industri di kawasan industry Pulogadung Jakarta". Jurnal Kedokteran Indonesia, Vol. 58 (1), pp. 8 - 12 .

Shahnavaz, H. 1987. "Workplace injuries in the developing countries". Ergonomics, Vol. 30 (2), pp. 397 - 404.

Simoneau, S.; St-Vincent, M.; Chicoine, D. 1996. WorkRelated Musculoskeletal Disorders (WMSDs) A Better Understanding for More Effective Prevention. Quebec: IRSST.

Velaga, P.; Telaprolu, N. 2013. "Work posture and prevalence of musculoskeletal symptoms among women in packing activities of pharmaceutical industry". International Journal of Current Research and Review, Vol.05, pp. $57-64$. 